\title{
MONTHLY
}

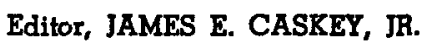

\section{AN OBJECTIVE AID FOR FORECASTING SEPTEMBER THUNDERSTORMS AT DENVER, COLO.}

\author{
KENNETH C. TILIOTSON \\ Weather Bureau Airport Station, Denver, Colo. \\ [Original manuscript received August 8, 1950; revised manuscript received February 12, 1951]
}

\begin{abstract}
The climatology of September thunderstorms at Denver, Colo., is discussed. Data as near as possible to the time of occurrence of thunderstorms are studied to determine variables related to the occurrence of thunderstorms. The same variables from earlier data are investigated to determine their forecasting value. Three variables taken from the $2000 \mathrm{MST}$ raobs and 700-mb. charts are ultimately used to obtain an objective aid for forecasting thunderstorms between midnight and midnight following the 2000 MST upper air chart. It is pointed out that for practical purposes this constitutes a forecast of afternoon and evening thunderstorms, or a forecast for 12-20 hours in advance.

- The conclusion is drawn that the objective aid developed should prove of value in forecasting September thunderstorms at Denver.
\end{abstract}

\section{CONTENTS}

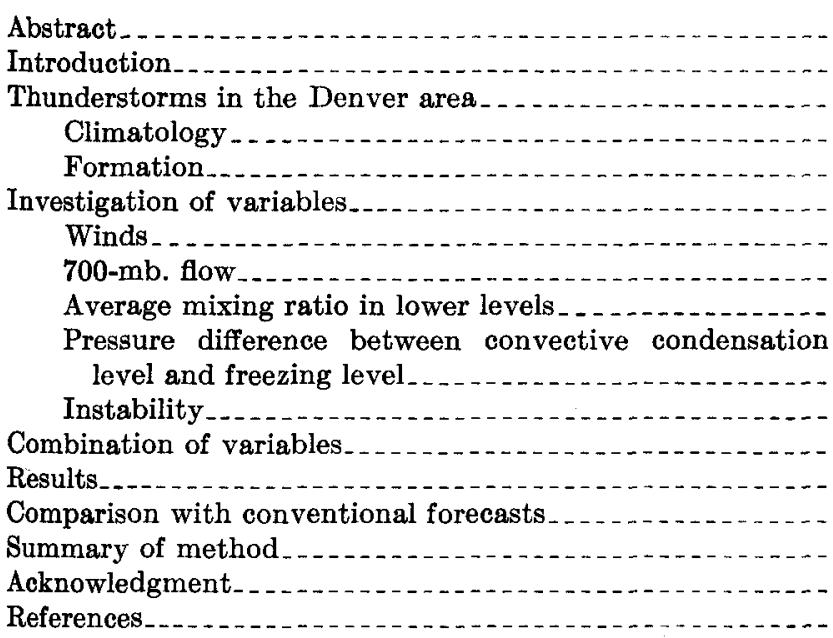

Page

27

27

27

28

29

29

29

30

30

\section{1}

31

32

$\mathbf{3 3}$

33

33

34

34

\section{INTRODUCTION}

Most thunderstorms observed at Denver occur during the warmer months of June, July, and August when the maximum solar insolation occurs. For this reason most thunderstorm studies for the Denver area have been limited to these months. For example, H. V. Hightman [1] studied the relationship of mixing ratios to thunderstorm occurrence during 1941 and 1942; and Legg [2] using the same years investigated the position of the freezing level and the convective condensation level in connection with Denver thunderstorms. Epperly [3] used the summer months for the study of thunderstorm probability for the western portion of the United States.

Thunderstorms do occur at Denver in September, however, and, while the average number of thunderstorms is only 4, as many as 13 have been observed. The shorter days of early fall have lower maximum temperatures due to the gradual reduction of the amount of solar insolation and the forecasting of thunderstorms during the latter part of the thunderstorm season becomes increasingly difficult. For this reason a separate study of September thunderstorms was made in an attempt to set up an objective forecasting aid.

Since an analysis of the upper air was deemed essential for the forecasting of thunderstorms, data for the 6-year period 1940-45, inclusive, were used in the development of the objective aid. This period includes the extremes in number of occurrences, from none during the month to the maximum of 13. A limited amount of $700-\mathrm{mb}$. data for 1946 was used in the preliminary stages. Raobs were not taken at Denver during 1946,1947 , or 1948 . With the resumption of raobs by Lowry Air Force Base, the 1949 and 1950 data became available for test purposes.

\section{THUNDERSTORMS IN THE DENVER AREA}

As background for the development of the forecasting aid, the climatology of September thunderstorms and important factors in thunderstorm formation in the Denver area are now discussed. 
CLIMATOLOGY

To supplement the information contained in a study of summer thunderstorms (May through September) made by A. W. Cook and the Denver forecasting staff [4], the 20-year period from 1928 through 1947 was studied to determine a few climatological facts about September thunderstorms.

There was a total of 83 thunderstorms during that period which gives an average of but 4.2 each year. The number varied from none in 1944 to 13 in 1940, as shown in figure 1A. Figure $1 \mathrm{~B}$ shows the departure by years of the monthly mean September maximum temperature from the normal September maximum, and also the departure of the average maximum temperature on days of thunderstorm occurrences. Maximum readings are generally higher on thunderstorm days. There seems to be no relationship between the number of occurrences for the

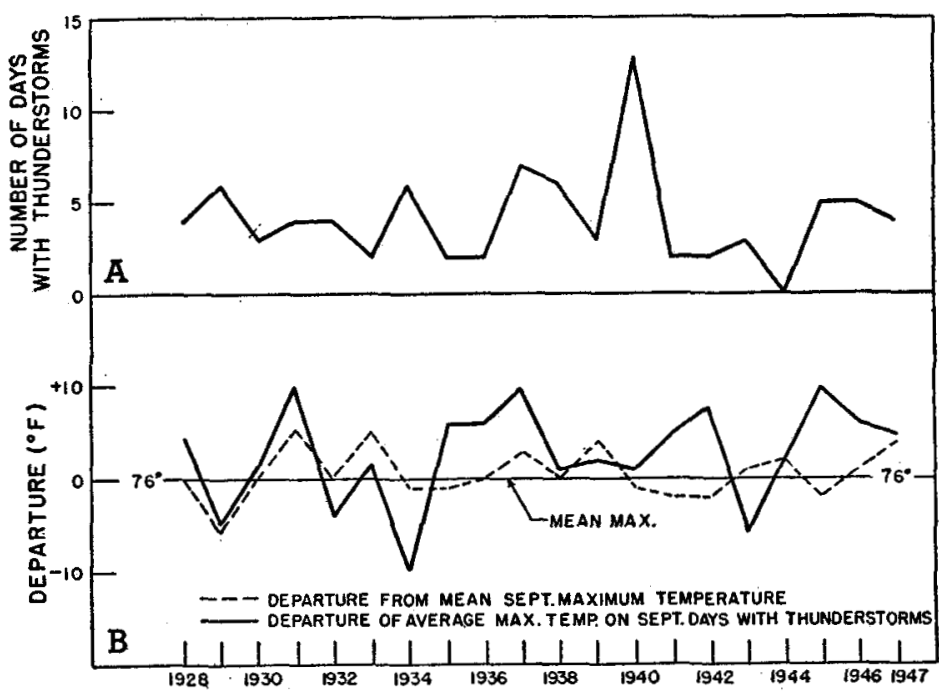

Ficure 1--(A) Number of days in September with thunderstorms at Denver, Colo. by years: $1828-47$. (B) Departure of the mean September maximum temperatur from the normal September maximum (dashed line), and departure of the average maximum temperature on days in September with thunderstorms (solid line), by years: 1928-47.

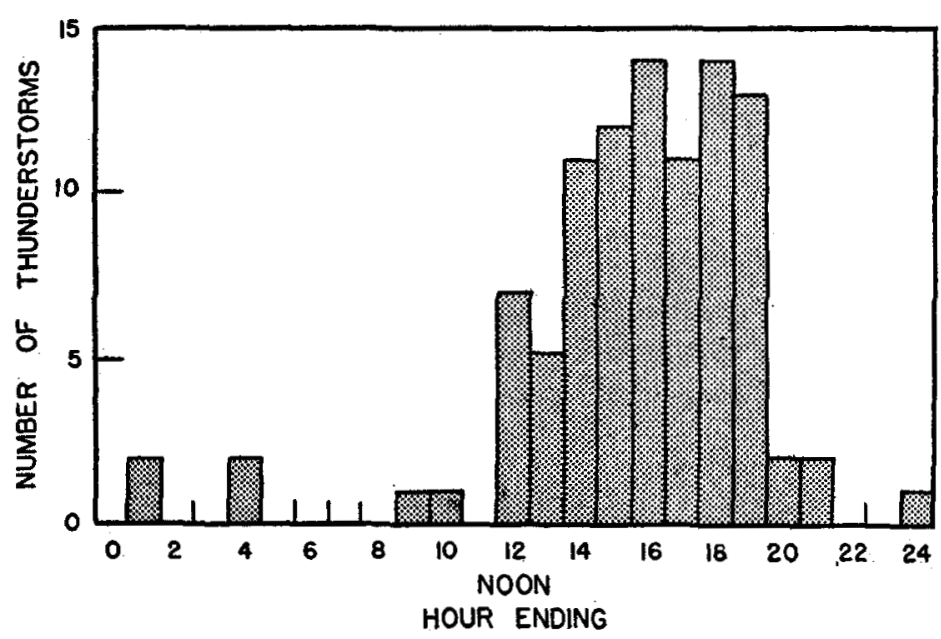

Figure 2,-Diurnal distribution of thunderstorms at Denver, Colo., September 1919-38 (Aiter Cook [5].) month and the mean maximum temperature for that month. Since September is a transition month between summer and fall, the mean maximum drops sharply from $84.3^{\circ} \mathrm{F}$. in August to $64.7^{\circ}$ in October with the September mean being $76.5^{\circ}$.

Figure 2 is taken from a previous statistical study [5] in which it was found that nearly all the thunderstorms in the period 1919-38 passed over Denver during the hours from 1200 to 2000 MST. Resultant maximum precipitation amounts in the afternoon and early evening are shown in figure 3. Since September is at the end of the thunderstorm season one might expect to find the curve of occurrences by days of the month (fig. 4) gradually sloping downward to the right, i. e., toward the end of the month. Instead, for the period 1928-47, there was a minimum from the 12 th to the $22 \mathrm{~d}$, with a maximum near the end of the first week and secondary maxima during the early

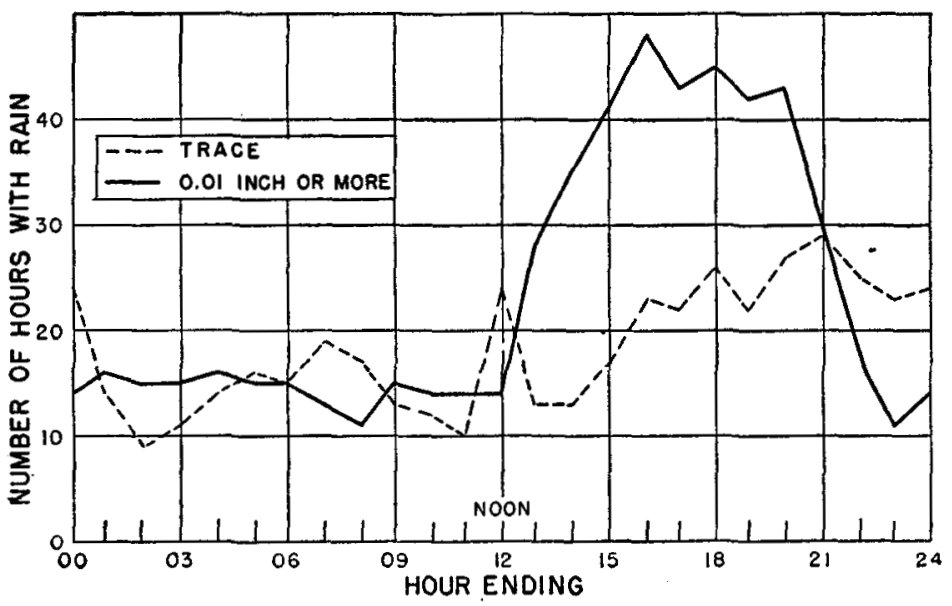

FIGUaE 3.-Diurnal distribution of number of hours with rain at Denver, Colo, September 1910-38. (After Cook [5].)

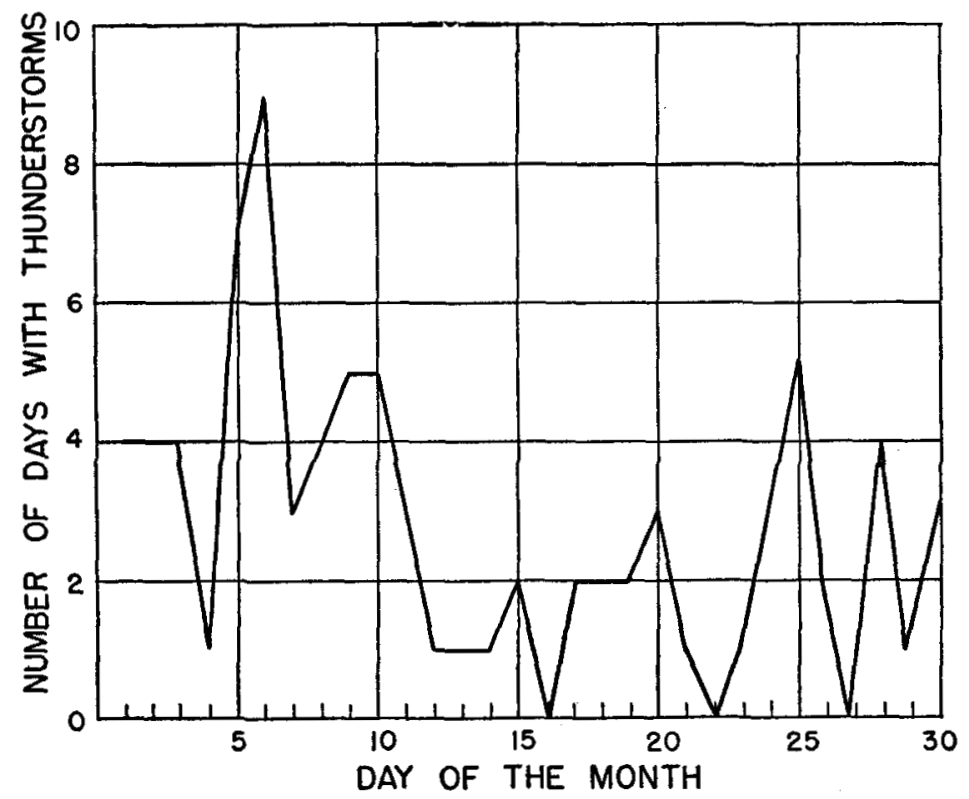

FIGURE 4.-Distribution of thunderstorm days by days of the month, September 1928-47. Total number of days with thunderstorms during the 20-7ear period was 83 . 
part of the second and during the fourth weeks. With such a small number of occurrences a few synoptic situations producing several consecutive days of convective activity during any one part of the month would add considerable weight to that portion of the curve. Table 1 shows the frequency of occurrence of thunderstorms on consecutive days.

TABLE 1.-Frequency of occurrence of thunderstorms on consecutive days Denver, Colo., September 1928-47

\begin{tabular}{|c|c|c|}
\hline $\begin{array}{c}\text { Number of } \\
\text { consecutive } \\
\text { days }\end{array}$ & $\begin{array}{c}\text { Number of } \\
\text { times of oc- } \\
\text { currence of } \\
\text { thunder- } \\
\text { storms }\end{array}$ & $\begin{array}{c}\text { Number of } \\
\text { times of oc- } \\
\text { currence of } \\
\text { thunder- } \\
\text { storms and/or } \\
\text { lightning * }\end{array}$ \\
\hline 1 & 42 & \\
2 & 15 & 22 \\
3 & 2 & 4 \\
4 & 0 & 1 \\
5 & 1 & 0 \\
7 & 0 & 0 \\
8 & 0 & 1 \\
\hline
\end{tabular}

*1939-47.

\section{FORMATION}

The "chimney effect" [4] is generally considered to be of prime importance in the strong convective activity and resultant thunderstorm generation immediately near a range of mountains. The east face of the Rockies is oriented perpendicular to the morning sun and as a result convective currents are set up in the hills and mountains before they are over the plains. The air thus heated over the higher terrain is less dense and rises. This produces a flow in the lower levels up the mountain side which affects the surface winds and the winds in the lower levels at least as far out on the plains as Denver, 40 miles away. Thus it might be said that air lying over the extreme western plains is drawn up the eastern slope of the Rockies which really acts as a steep front with a slope of $1: 30$. Denver has an elevation of 5,300 feet above sea level while the main range averages about 12,300 feet which gives approximately a $1 \frac{1}{3}$-mile rise in 40 miles, or a slope of 1 to 30 . In this case the air is moving up the stationary surface instead of a moving frontal surface lifting the air, but the result is the same.

In this connection it might be well to point out the importance of Mount Evans, 40 miles west-southwest of Denver. This peak, which is a part of the eastern range of the Rockies, is a pronounced mountain jutting eastward from the range; it is connected to the range by high terrain on the western side only, with the remaining three sides dropping from the elevation of 14,259 feet above sea level down to 7,000 feet in 10 or 12 miles. Solar insolation on the north slopes is quite small, however, very active heating takes place on the eastern and southern slopes. This increases the intensity of the general chimney effect of the main range described above. Forecasters keenly watch the summer convective activity developing over this peak since it appears that these storms are the ones which most often pass over the local Denver area.

940551-51-2
A review of the surface charts showed that thunderstorms occur quite frequently from just after a maritime polar frontal passage to as long as two days afterward. The moisture transported into the western plains by the fresh influx of $\mathrm{mP}$ air in the lower levels apparently contributes added moisture to increase convective instability and resultant overturning as the air rises up the east face of the Rockies.

Lightning at first was considered to be significant, insofar as visible lightning might be indicative of thunderstorm activity in the general area. However, as stated in a Weather Bureau report [6], "The occurrence of lightning without thunder is not designated as a thunderstorm. The occurrence is reported, of course, but it is not included in the usual summation of thunderstorm days or occurrences. This practice diminishes the area for which a single station can be considered representative of thunderstorm occurrences, the radius of audibility of thunder being much less, ordinarily, than the radius of visibility of lightning. It is also true, however, that the visibility is much greater at night than in the daylight, so that a diurnal variation of frequency based on lightning occurrences would not be representative." Upon investigation it was found that nearly all the lightning at Denver was observed from the northeast through southeast. Nocturnal thunderstorms which so commonly occur over the western Great Plains in the summer can be observed easily from Denver when occurring as far east as the ColoradoKansas border 150 miles away. Since this type of thunderstorm does not occur in the Denver area, but rather within sight in the east quadrant, lightning was not considered significant, although the data were entered on some of the charts, separate from thunderstorms. Some late evening lightning also occurs over the Continental Divide immediately west of Denver, but storms over the mountains at that time of day nearly always dissipate before reaching Denver.

\section{INVESTIGATION OF VARIABLES}

In the development of the forecasting aid, many variables were investigated which were thought to be related to the formation or movement of thunderstorms for this local area. Conditions which existed during the morning of the day of occurrence were studied first. From this study variables were found that should be investigated from similar data for an earlier time; the time lag was chosen so that thunderstorms could be forecast from data available to the forecaster at about midnight. The forecast period was considered to be from midnight to midnight, but for all practical purposes, as shown by the diurnal distribution of thunderstorms in figure 2, the forecast is for afternoon and evening thunderstorms. -

WINDS

For summer thunderstorm occurrences at Denver, Cook and the Denver Forecasting Staff [4] found that "at approximately 10,000 feet MSL the direction of winds 


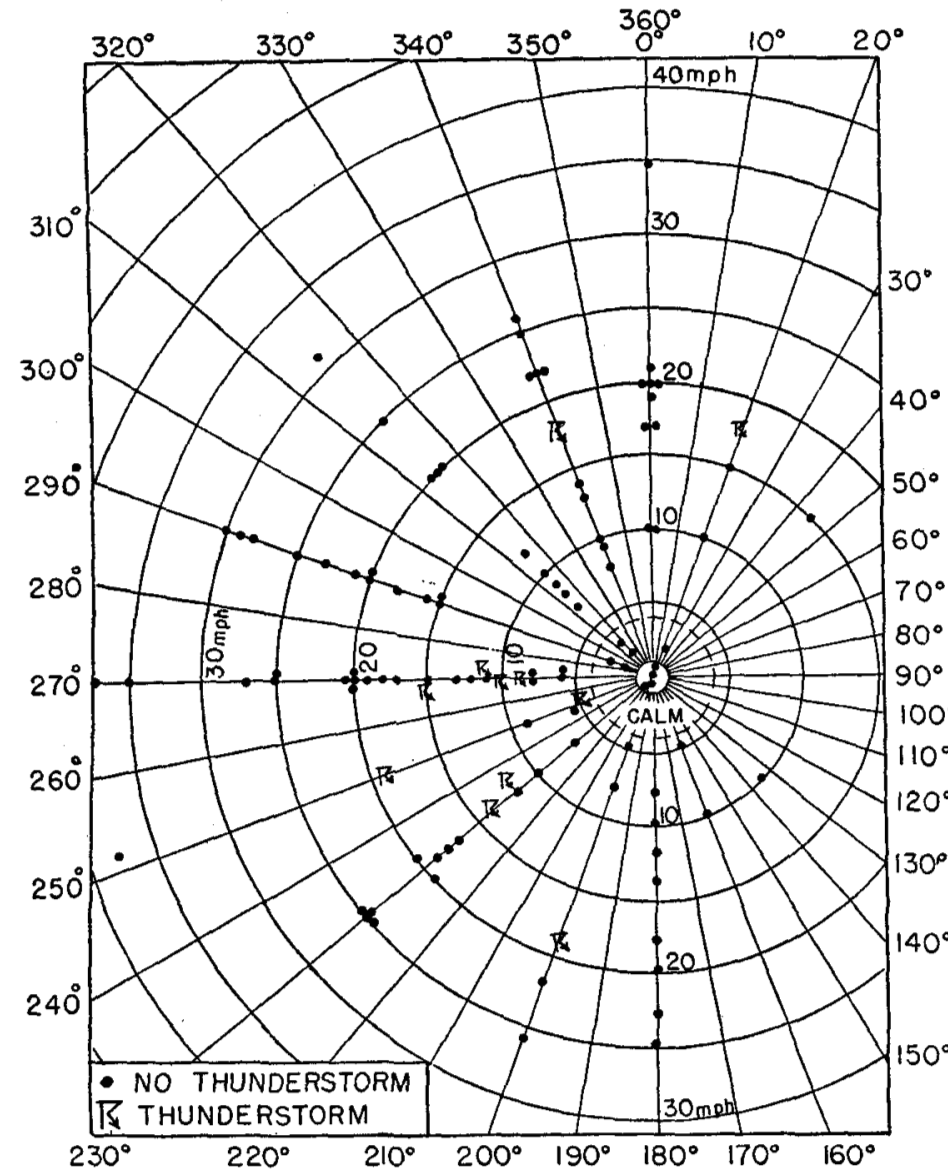

Fioure 5.-Wind at 700-mb. level at Denver, Colo., 0800 MST daily, September 1943-46, with plotted symbol indicating occurrence of thunderstorm ([G) or no thunderstorm $(\bullet)$ on the same day.

varied from south clockwise to east-northeast, with southwest and south predominating. The movement of the convective type storm seems to be definitely connected with the winds aloft. In many cases the storms move away from the mountains in a direction comparable to that of the winds at about 11,000 feet MSL. This corresponds to Brancato's findings in the Ohio Valley that thunderstorms move with the speed of the 4-6,000 feetabove-surface winds." Since the elevation at Denver is 5,300 feet, winds $4,000-6,000$ feet above the surface would be near the 10,000-11,000-foot MSL level.

The height of the $700-\mathrm{mb}$. level during September is usually between 10,000 and 10,600 feet, therefore the 0800 MST 10,000 -foot or $700-\mathrm{mb}$. winds at Denver for the 4 years $1943-46$ were plotted on polar coordinate paper with thunderstorm occurrence represented by a thunderstorm symbol. See figure 5. Of the winds with velocities above $5 \mathrm{mph}$., 94 percent were found to be from south through west to north, inclusive. Fifty-three percent were from south to west, inclusive. Sixty-nine percent (9/13) of all thunderstorms occurred with winds southwesterly to westerly, inclusive, which, qualitatively, are the same results as found for the midsummer thunderstorms.

No thunderstorms occurred with southeasterly winds. These winds are produced by a 700-mb. Low over New
Mexico, Arizona, or eastern Colorado. Two storms occurred with northerly quadrant winds, but strong cold air advection at upper levels produced unusually unstable lapse rates at higher levels which may account for these.

Wind speeds at 10,000 feet on thunderstorm days were usually $8-20 \mathrm{mph}$. It is thought that stronger winds tend to tear off the tops of the buildups preventing them from fully developing into cumulonimbi.

\section{0-MB. FLOW}

A preliminary study of the 0800 MST $700-\mathrm{mb}$. flow showed that a general southwesterly to westerly flow over the Denver area seemed to be necessary for occurrence of a thunderstorm at Denver, which is in agreement with the results indicated in the analysis of the 10,000-foot wind in the preceding paragraphs. This flow was found to prevail 62 percent of all days during the two September months investigated, with all thunderstorms occurring when this type of flow existed.

As a simple objective measure of this flow at $2000 \mathrm{MST}$, the height difference between Denver and Boise was tabulated. This measure of gradient was chosen to the west of Denver to allow for the general easterly movement of the upper air patterns. A large positive value of this difference (Denver minus Boise) indicates a strong southwesterly flow. Table 2 shows the percent frequency of occurrence of thunderstorms in class intervals of the height difference, with higher percentages of occurrence with larger positive values of the difference.

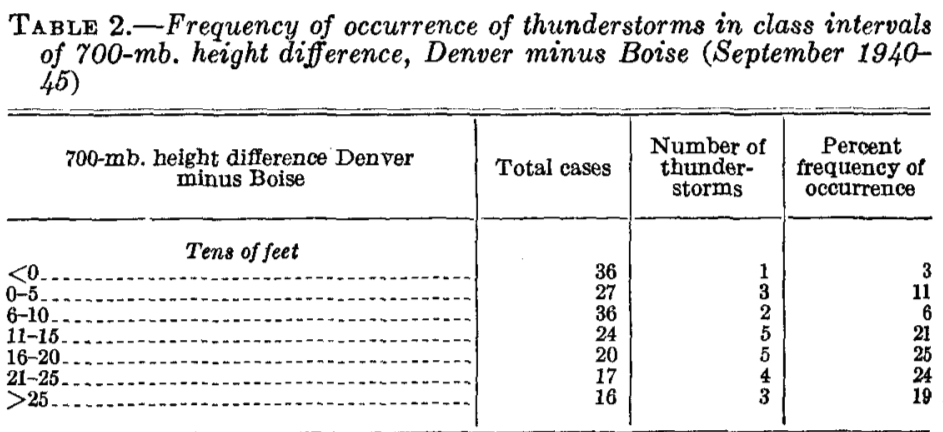

AVERAGE MIXING RATIO IN LOWER LEVELS

One method [1] of determing the average mixing ratio in analyzing instability of air uses the moisture in the friction layer, considered to be below the top of the inversion, or if the inversion is destroyed by $1000 \mathrm{MST}$, the layer $40 \mathrm{mb}$. above the surface. Another [3] averages values from the surface to the $500-\mathrm{mb}$. level "bearing in mind that the air below the free convection level will be thoroughly mixed by the time the critical temperature for the day is reached." Much this latter line of reasoning was used in this study when mixing ratio values from the surface through the $700-\mathrm{mb}$. level were averaged. The average was computed by the formula $\bar{w}=\frac{\Sigma w}{N}$. The convective condensation levels were found to vary from approximately 580 to $670 \mathrm{mb}$., or 6,000 to 9,000 feet above 
TABLE 3.-Frequency of occurrence of thunderstorms in class intervals of average mixing ratio in layer surface to $700 \mathrm{mb}$. (September $1940-45)$

\begin{tabular}{|c|c|c|c|}
\hline Average mixing ratio surface to $700-\mathrm{mb}$. & Total cases & $\begin{array}{l}\text { Number of } \\
\text { thunder- } \\
\text { storms }\end{array}$ & $\begin{array}{l}\text { Percent fre- } \\
\text { quency of } \\
\text { occurrence }\end{array}$ \\
\hline 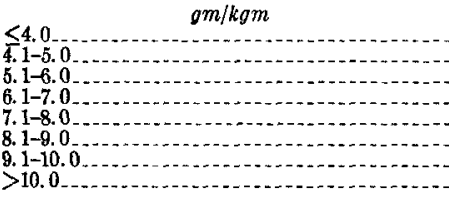 & $\begin{array}{r}22 \\
37 \\
43 \\
21 \\
21 \\
16 \\
9 \\
7\end{array}$ & $\begin{array}{l}1 \\
0 \\
4 \\
3 \\
5 \\
3 \\
2 \\
5\end{array}$ & $\begin{array}{r}4 \\
0 \\
9 \\
14 \\
24 \\
19 \\
22 \\
71\end{array}$ \\
\hline
\end{tabular}

the surface. Since mixing ratio values are not available at any consistent level above $700 \mathrm{mb}$., for the sake of uniformity no values were used above that level. $\mathrm{By}$ using this method moisture was averaged throughout approximately the lower 4,700 feet above ground.

A strong relationship was found to exist between the average mixing ratio at $0800 \mathrm{MST}$ and the occurrence of thunderstorms the same day. The average mixing ratios from the $2000 \mathrm{MST}$ raobs were therefore analyzed; the results are shown in table 3 . There was a very marked increase in frequency of occurrence with higher values of the average mixing ratio.

The mixing ratio at $700 \mathrm{mb}$. alone was also investigated, and, while a relationship existed, it did not appear to be as strong or significant as the relationship between the average mixing ratio and the occurrence of thunderstorms.

PRESSURE DIFFERENCE BETWEEN CONVECTIVE CONDENSATION LEVEL AND FREEZING LEVEL

The 0800 MST raob data were used to determine the relationship of the pressure difference between convective condensation level and freezing level and the occurrence of thunderstorms the same day. Legg [2] used data for the warm summer months, June, July, and August for 1941 and 1942, using a rather shallow layer for determining mixing ratios. Essentially the same results were obtained for September for the 3-year period, 1943, 1944, and 1945, using the average mixing ratio as described above to determine the convective condensation level. During September the mean difference between the condensation level and the freezing level was $57 \mathrm{mb}$. while Legg found 60 . In September the greatest difference was $180 \mathrm{mb}$. while 140 was the greatest for the summer months. The lowest pressure at which the condensation level was found was the same in both studies, $510 \mathrm{mb}$., although all but one case in September were below $585 \mathrm{mb}$. $(14,500 \mathrm{ft}$.).

Only one thunderstorm occurred when the condensation level was significantly higher in elevation than the freezing level, and that occurred when the cold air advection at upper levels was relatively strong, which type of advection lowers the condensation level, assuming no change in the lower levels. Some moisture in the form of liquid drops appears essential for thunderstorm formation.

A similar analysis of 2000 MST raobs for the 6 years 1940-45, inclusive, gave approximately the same results.
TABLE 4.-Frequency of occurrence of thunderstorms in class interval of pressure difference between the convective condensation level and the freezing level (September 1940-45)

\begin{tabular}{c|r|r|r}
\hline Pressure difference & Total cases & $\begin{array}{r}\text { Number of } \\
\text { thunder- } \\
\text { storms }\end{array}$ & $\begin{array}{r}\text { Percent fre- } \\
\text { quency of } \\
\text { occurrence }\end{array}$ \\
\hline$m b$. & & & \\
\hline $0-24$ & 103 & 4 & 4 \\
$250-49$ & 21 & 4 & 19 \\
\hline $50-74$ & 16 & 4 & 29 \\
\hline
\end{tabular}

If the condensation level was near or below the height of the freezing level, there was a good possibility of a thunderstorm the following day. Table 4 shows the frequency of occurrence of thunderstorms in class intervals of the pressure difference, a positive value of the difference indicating that the condensation level is below the freezing level. This table also shows a marked increase in the frequency of thunderstorms with greater values of the pressure difference.

\section{INSTABILITY}

Considerable analysis was made of a number of years of raobs to find a good objective tool for measuring instability. First, the decrease of pseudo wet-bulb temperature between the levels 850 and $550 \mathrm{mb}$. was found to be closely related to thunderstorm occurrence. It was found that the probability of occurrence was very small if the decrease between those levels was less than $5^{\circ} \mathrm{C}$ This method entailed plotting the raob on a larger adiabatic chart than is now currently used at Denver and also plotting the additional pseudo wet-bulb curve. Table 5 shows how the frequency of occurrence of thunderstorms increases with greater convective instability.

TABLE 5.-Frequency of occurrence of thunderstorms in class intervals of change of the pseudo wet-bulb temperature from 850 to 550 $m b$. A negative value indicates a decrease of temperature with height (September 1948, 1944, 1945)

\begin{tabular}{|c|c|c|c|}
\hline $\begin{array}{l}\text { Change in pseudo wet-bulb temperature } \\
\text { from } 850 \text { to } 550-\mathrm{mb} \text {. level }\end{array}$ & Total cases & $\begin{array}{l}\text { Number of } \\
\text { thunder- } \\
\text { storms }\end{array}$ & $\begin{array}{l}\text { Percent } \\
\text { frequency of } \\
\text { occurrence }\end{array}$ \\
\hline $\begin{array}{l}{ }^{\circ} C \\
>0 \\
0 \text { to }-2.4 \\
-2.5 \text { to }-4.9 \\
-5.0 \text { to }-7.4 \\
-7.5 \text { to }-9.9 \\
<-100 \text { to }-12.4 \\
<-12.4\end{array}$ & $\begin{array}{r}21 \\
26 \\
17 \\
11 \\
7 \\
2 \\
5\end{array}$ & $\begin{array}{l}1 \\
0 \\
0 \\
3 \\
3 \\
1 \\
0\end{array}$ & $\begin{array}{r}3 \\
27 \\
43 \\
50 \\
0\end{array}$ \\
\hline
\end{tabular}

Another measure of the instability is the temperature drop between 800 and $500 \mathrm{mb}$. This is essentially the same layer as used in the above method, but without moisture being taken into account. Table 6 shows the relationship between this measure of instability at 2000 MST and the occurrence of thunderstorms the following day.

Still another measure of instability is the difference between the surface dew point and the 500-mb. temperature. This measure combines surface moisture with the instability factor described in the preceding paragraph. The 
TABLE 6.--Frequency of occurrence of thunderstorms in class intervals of change of temperature from $800 \mathrm{mb}$. to $500 \mathrm{mb}$. (September 1943, $1944,1945)$

\begin{tabular}{|c|c|c|c|}
\hline Decrease in temperature from 800 to $500 \mathrm{mb}$. & Total cases & $\begin{array}{l}\text { Number of } \\
\text { thunder- } \\
\text { storms }\end{array}$ & $\begin{array}{l}\text { Percent fre- } \\
\text { quency of } \\
\text { oecurrence }\end{array}$ \\
\hline $\begin{array}{c}{ }^{\circ} C . \\
\langle 20-24 \\
250-29 \\
34\end{array}$ & $\begin{array}{r}6 \\
8 \\
37 \\
34 \\
4\end{array}$ & $\begin{array}{l}0 \\
0 \\
3 \\
5 \\
0\end{array}$ & $\begin{array}{r}0 \\
0 \\
8 \\
15 \\
0\end{array}$ \\
\hline
\end{tabular}

TABLE 7.-Frequency of occurrence of thunderstorms in class intervals of temperature difference between surface dew point and $500-m b$. temperature. (September 1940-45)

\begin{tabular}{|c|c|c|c|}
\hline $\begin{array}{l}\text { Difference between surface dew point and } \\
\text { 500-mb. temperature }\end{array}$ & Total cases & $\begin{array}{l}\text { Number of } \\
\text { thunder- } \\
\text { storms }\end{array}$ & $\begin{array}{l}\text { Percent fre- } \\
\text { quency of } \\
\text { occurrence }\end{array}$ \\
\hline 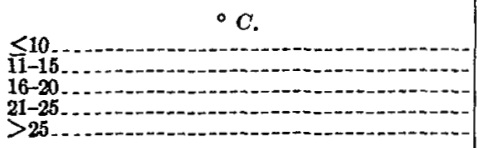 & $\begin{array}{r}17 \\
62 \\
66 \\
28 \\
3\end{array}$ & $\begin{array}{l}2 \\
2 \\
7 \\
9 \\
3\end{array}$ & $\begin{array}{r}12 \\
3 \\
11 \\
32 \\
100\end{array}$ \\
\hline
\end{tabular}

dew point used was the one at $2030 \mathrm{MST}$, synoptic with the raob ascent. Table 7 shows the relationship between this measure of instability at $2000 \mathrm{MS}$ T and the occurrence of thunderstorms the following day.

\section{COMBINATION OF VARIABLES}

From the variables discussed in the foregoing section three were ultimately combined to form the objective aid for forecasting thunderstorms at Denver. These three were: (1) the beight difference at $700 \mathrm{mb}$. between Denver and Boise, (2) the temperature difference between the surface dew point and the 500-mb. air temperature, and (3) the pressure difference between the convective condensation level and the freezing level. The second variable above was chosen instead of the more theoretically sound "change of pseudo wet-bulb temperature with height" because of its apparent strong relationship to the occurrence of thunderstorms and its simplicity of computation.

Due to the fact that the average mixing ratio from the surface to $700 \mathrm{mb}$. is used to determine the convective condensation level, there is a high correlation between the average mixing ratio and the pressure difference between the convective condensation level and the freezing level. The average mixing ratio was therefore not used as a separate variable.

There is also, of course, a certain amount of interdependence between the variables 2 and 3 above. The only variable which can be considered as independent of the others is the $700-\mathrm{mb}$. height difference between Denver and Boise. Essentially the same results are

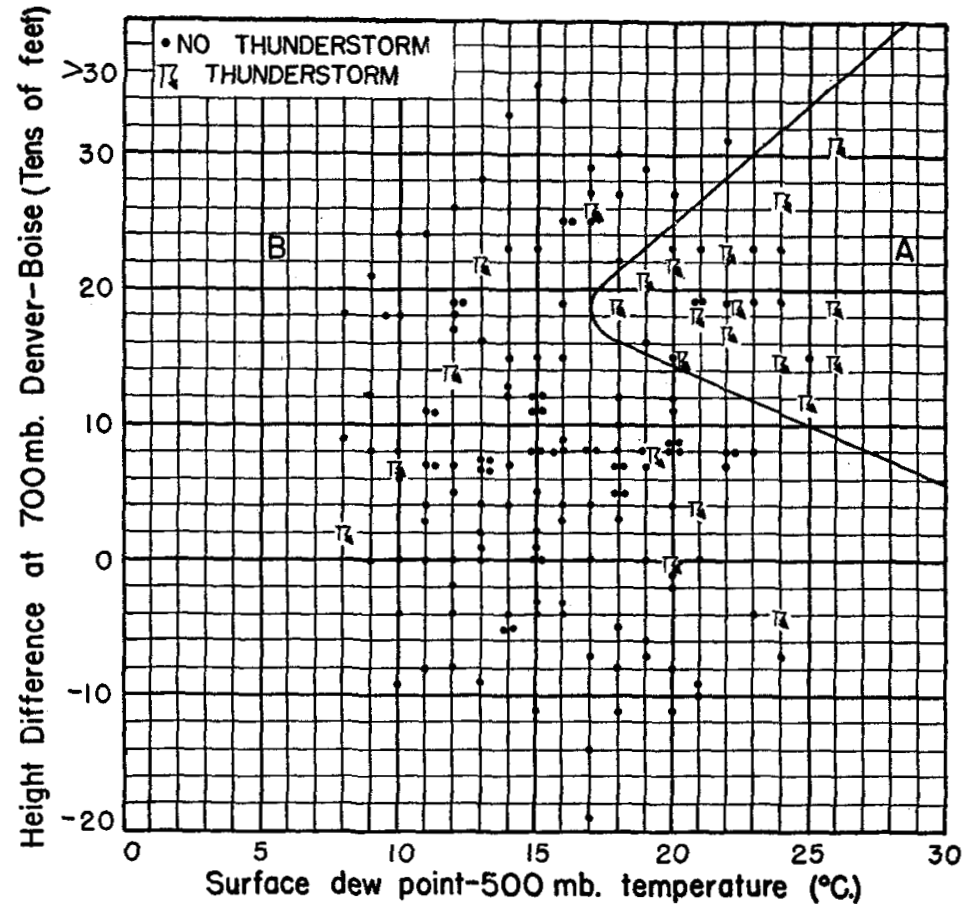

Flotre 6.-Scatter diagram of thunderstorm $(\mathbb{\Omega})$ and no thunderstorm $(\bullet)$ days at Denver, Colo., as related to the $2000 \mathrm{MST}$ height difference at $700 \mathrm{mb}$. between Denver and Boise and the $2000 \mathrm{MST}$ surface dew point minus $500-\mathrm{mb}$. temperature at Denver. All cases, September 1940-45.

obtained regardless of the order in which the variables are combined. The two variables which are most readily computed are therefore combined first so that the third variable need not be computed unless the first two show a high probability of thunderstorm occurrence.

In figure 6 the $700-\mathrm{mb}$. height difference between Denver and Boise is plotted against the temperature difference between the surface dew point and the 500-mb. temperature, with a "no-thunderstorm" day being entered as a dot and a "thunderstorm" day as a thunderstorm symbol.

The best separation of thunderstorm days from nothunderstorm days is obtained by the line as indicated in figure 6. The reversal of the relationship of the height difference to the occurrence of thunderstorms when the height difference becomes greater than 200 feet tends to bear out the statement made earlier that strong winds aloft tend to tear off the tops of the buildups preventing them from fully developing into cumulonimbi. The separation obtained on this chart is 54 percent (14/26) frequency of occurrence of thunderstorms in the small area delineated by the lines on the chart (area A), and 6 percent $(9 / 143)$ frequency of occurrence over the rest of the chart (area B). It is of interest to note that of the 12 nonoccurrences in area $A, 7$ were showers.

The application of the third variable - the pressure difference between the convective condensation level and the freezing level-improves the results only slightly on a yes or no basis, as it eliminates only two of the nonoccur rences. If the difference is large enough, however, it 
TABLE 8.-Relationship of pressure difference between convective condensation level and freezing level to the frequency of occurrence of thunderstorms for cases falling only in area $A$ of figure 6

\begin{tabular}{c|r|r|r}
\hline \hline Pressure difference & Total cases & $\begin{array}{c}\text { Number of } \\
\text { thunder- } \\
\text { strm ocur- } \\
\text { rences }\end{array}$ & $\begin{array}{c}\text { Percentage } \\
\text { of occur- } \\
\text { rences }\end{array}$ \\
\hline$m b$. & & & \\
\hline$>-20$ & 2 & 0 & 0 \\
\hline$>+80+80$ & 6 & 5 & 50 \\
\hline
\end{tabular}

\section{RESULTS}

increases considerably the probability of getting a thunderstorm, as shown in table 8. A thunderstorm forecast is made if the difference is equal to or greater than $-20 \mathrm{mb}$.

The results of applying the three variables to the original data (1940-45) are summarized in table 9 . The skill score is based on the marginal totals of the contingency table.

The test data (1949 and 1950) are summarized in tables 10 and 11. The number of cases is small, but the results tend to bear out the percentages observed in the original data.

TABLE 9.-Contingency table of "forecasts" of thunderstorms on the original data, September 1940-45

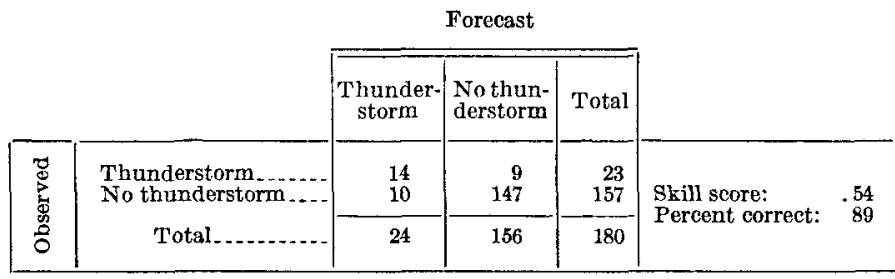

TABLE 10.-Percentage of occurrence of thunderstorms in the two areas delineated on figure 6. (Test data September 1949 and 1950)

\begin{tabular}{r|r|r|r}
\hline \hline Area from figure 6 & Total cases & $\begin{array}{r}\text { Number of } \\
\text { thunderstorm } \\
\text { occurrences }\end{array}$ & $\begin{array}{c}\text { Percentage } \\
\text { of occurrence }\end{array}$ \\
\hline A & 10 & 4 & 40 \\
\hline
\end{tabular}

Table 11.-Frequency of occurrence of thunderstorms in class intervals of pressure difference between the convective condensation level and the freezing level. For cases falling in area $A$ of figure 6. (Test data September 1949 and 1950)

\begin{tabular}{l|r|r|r}
\hline \hline Pressure difference & Total cases & $\begin{array}{c}\text { Number of } \\
\text { thunderstorm } \\
\text { occurrences }\end{array}$ & $\begin{array}{c}\text { Percentage } \\
\text { of occurrences }\end{array}$ \\
\hline$<-20$ & 1 & 0 & 0 \\
\hline$>+80+80$ & 9 & 45 \\
\hline
\end{tabular}

\section{COMPARISON WITH CONVENTIONAL FORECASTS}

In order to obtain at least an indication of whether the objective aid may prove of use in daily forecasting, a comparison was made with the official forecasts for Denver and vicinity made at about 0230 MST for that day and the following night. Any mention of thunderstorms whatsoever except "thunderstorms along the mountains" was considered a thunderstorm forecast. There can be no argument about a miss being made if thunderstorms are not mentioned in the forecast but one is recorded at the station. However, the argument can be advanced, and perhaps justifiably, that the forecast for Denver and vicinity is for a radius of 20 miles and thunderstorms might well occur in this area which are not heard at the station. This accounts in part for the tendency for forecasting more thunderstorms than are observed at the airport station. However, the same argument can be applied to those days on which the objective method forecasts thunderstorms and none is recorded at the station. On 4 of the 5 days during September 1949 and 1950 on which the objective forecast was for thunderstorms and none occurred, the official forecast also called for thunderstorms. Table 12 shows the contingency tables for the official and objective forecasts for the two test months with the skill scores and percentage correct indicated.

TABLE 12.-Contingency tables for official and objective forecasts for the test data, September 1949 and 1950

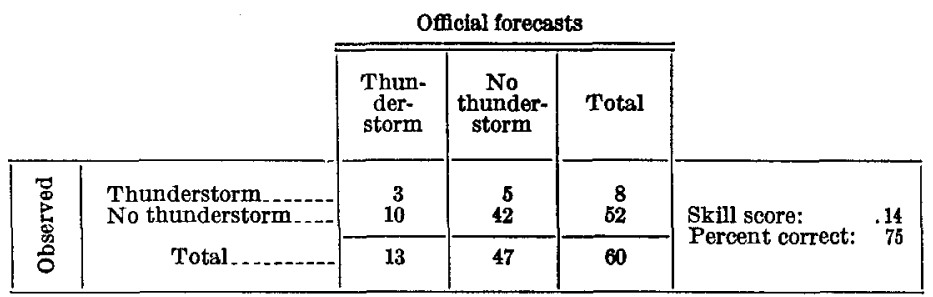

\begin{tabular}{|c|c|c|c|c|c|c|}
\hline & \multicolumn{3}{|c|}{ Objective forecasts } & & \\
\hline & & $\begin{array}{l}\text { Thun- } \\
\text { der- } \\
\text { storm }\end{array}$ & $\begin{array}{c}\text { No } \\
\text { thunder- } \\
\text { storm }\end{array}$ & Total & & \\
\hline \multirow{2}{*}{ 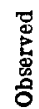 } & \multirow{2}{*}{$\begin{array}{l}\text { Thunderstorm } \\
\text { No thunderstorm } \\
\text { Total }\end{array}$} & $\begin{array}{l}4 \\
5\end{array}$ & $\begin{array}{r}4 \\
47\end{array}$ & $\begin{array}{r}8 \\
52\end{array}$ & \multirow{2}{*}{$\begin{array}{l}\text { Skill score: } \\
\text { Percent correct: }\end{array}$} & \multirow{2}{*}{$\begin{array}{r}.38 \\
85\end{array}$} \\
\hline & & 9 & 51 & 60 & & \\
\hline
\end{tabular}

The above comparison is not intended as "proof" of any sort, but it is presented only as an indication that the objective procedures compare very favorably with the forecasts being issued. Two months of independent data are not enough to adequately test any procedure, but the evidence at hand points to the conclusion that this objective aid should prove to be a useful tool in future forecasting of September thunderstorms at Denver. A number of years of use will be necessary to prove or disprove its value as a forecast aid.

\section{SUMMARY OF METHOD}

The forecast period for thunderstorm forecasting is from midnight to midnight, which, for all praetical purposes as shown by the diurnal distribution, is for after- 
noon and evening thunderstorms. The steps taken in making a forecast by this method are:

1. Determine the difference between the surface dew point and the 500-mb. temperature in degrees Centigrade.

2. Determine the height difference (in tens of feet) at $700 \mathrm{mb}$. between Denver and Boise.

3. Enter figure 6 with values from steps 1 and 2 .

4. If the case falls in area $\mathrm{A}$ of figure 6 determine the pressure difference in millibars between the convective condensation level and the freezing level.

5. If the value from step 4 is equal to or greater than $-20 \mathrm{mb}$., forecast a thunderstorm; if less than $-20 \mathrm{mb}$., forecast no thunderstorm.

6. If case falls in area $B$ of figure 6 , forecast no thunderstorm.

\section{ACKNOWLEDGMENT}

The author wishes to convey thanks to Mr. Woodrow Dickey, Research Forecaster, for his valuable assistance in the preparation of this paper.

\section{REFERENCES}

1. H. V. Hightman, Mixing Ratio in Connection With Thunderstorms at Denver, Colorado, U. S. Weather Bureau, Denver, 1942. (Unpublished.)

2. E. M. Legg, A Study of the Position of the $0^{\circ}$ Isotherm and the Convective Condensation Level in Connection With Thunderstorms at Denver, Colo., U. S. Weather Bureau, Denver, 1943. (Unpublished.)

3. Perry Epperly, A Practical Chart for Use in Thunderstorm Forecasting, U. S. Weather Bureau, Salt Lake City, 1942. (Unpublished.) (Paper presented at American Meteorological Society meeting, Salt Lake City, June 1942.)

4. A. W. Cook and Denver Forecasting Staff, Thunderstorm and Shower Forecasting at Denver, Colo., U. S. Weather Bureau, Denver, 1942. (Unpublished.)

5. A. W. Cook, "The Diurnal Variation of Summer Rainfall at Denver," Monthly Weather Review, vol. 67, No. 4, April 1939, pp. 95-98.

6. U. S. Weather Bureau, "Thunderstorm Rainfall," Hydrometeorological Report No. 5, Waterways Experiment Station, Vicksburg, Miss., 1947, pp. 1-2. 